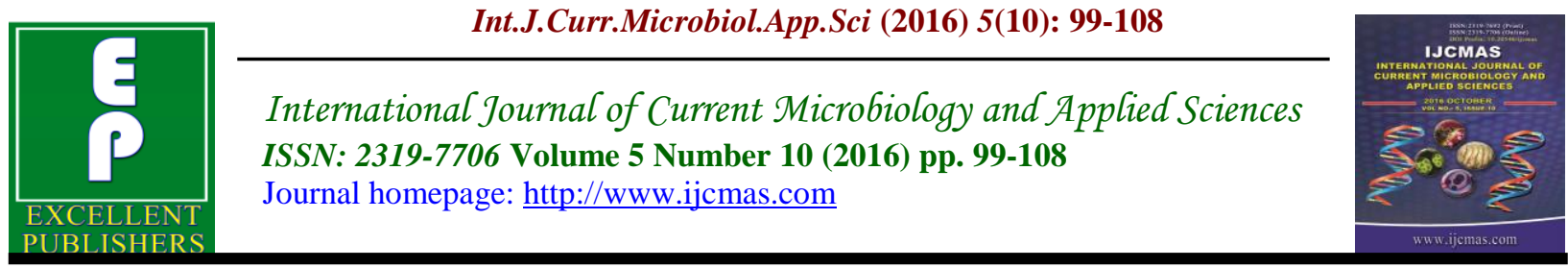

Original Research Article

http://dx.doi.org/10.20546/ijcmas.2016.510.012

\title{
Production of Cellulase in Submerged Fermentation using Water Hyacinth as Carbon Source and Reutilization of Spent Fungal Biomass for Dye Degradation
}

\author{
C. Pothiraj ${ }^{1 *}$, R. Arumugam ${ }^{2}$ and R.M. Gobinath ${ }^{2}$ \\ ${ }^{1}$ Department of Botany, Government Arts College, Melur - 625 003, Tamilnadu, India \\ ${ }^{2} \mathrm{PG} \&$ Research Department of Botany, Alagappa Government Arts College, \\ Karaikudi - 630 003, Tamilnadu, India \\ *Corresponding author
}

\begin{abstract}
A B S T R A C T
Keywords

Water hyacinth, Trichoderma viride and Aspergillus niger, Cellulase, laccase.

\begin{tabular}{l}
\hline Article Info \\
\hline Accepted: \\
12 September 2016 \\
Available Online: \\
10 October 2016
\end{tabular}

Cellulase enzyme production using water hyacinth biomass (WHB) as carbon source in submerged fermentation by Trichoderma viride and Aspergillus niger was studied. The FTIR spectral studies revealed that WHB had fermentable content of cellulose and hemicellulose. The fungal strains T. viride and A. niger, produced maximum cellulase at optimum culture condition with a substrate concentration of $5 \%(\mathrm{w} / \mathrm{v})$ and incubation period of 6 days $(72 \mathrm{hrs})$. The partially purified crude enzyme obtained from the $72 \mathrm{hr}$ culture of $T$. viride showed total cellulase activity (FPase) of 68.3 (IU) whereas, A. niger showed 46.3 (IU). The maximum CMCase enzyme production of 98.4 (IU) was exhibited by $T$. viride followed by A. niger 72.3 (IU). The spent fungal biomass from cellulase production media was reutilized for dye degradation potential. The present study showed that both the fungal spent biomass had moderate dye de-colourization (66\%) potential and significant laccase activity (3.4 IU).
\end{abstract}

\section{Introduction}

Cellulases are enzymes largely focused on by researchers and industries for the production of liquid fuel and other chemicals which are potential substitutes for petroleum derivatives (Bozell and Petersen, 2010). Cellulase is a group of enzymes which have the capability of hydrolyzing cellulose into fermentable sugars such as glucose, which can be used for producing many useful products such as ethanol, biofuel and other useful chemicals from the cellulosic feedstocks. Cellulase could be produced from many lignocellulosic feed stocks such as straws, bagasse, wheat bran, corn stover, corncob, etc (Camassola and Dillon, 2009). Terrestrial and aquatic weedy biomass are gaining much importance in these days because of its low cost, easy and decentralized availability for the biological production of industrial chemicals such as lactic acid, acetic acid, propionic acid and ethanol. Several scientists reported that 
different agricultural wastes especially water hyacinth as one of the substrate for cellulase production by using fungi (Fayyaz et al., 2009; Okunowo et al., 2010).

Water hyacinth (Eichhornia crassipes), was known as one of the fastest growing plants and a kind of unwanted species and the large-scale outbreak of it leads to many environmental problems in India. In order to resolve the problems, water hyacinth has been used for producing biogas (Singhal and Rai, 2003), ethanol (Mishima et al., 2008) and high caloric fuel (Lu et al., 2009). Water hyacinth have high content of hemicellulose (35 to $55 \%$ of dry mass), cellulose (18\% of the dry mass) and protein (13\% of the dry mass), which can provide enough nutrients for cellulase production by many microbial strains (Zhao et al., 2011). Therefore, the present study focuses on the enriched production of cellulases by natural fungal isolates using water hyacinth biomass as carbon source under controlled environment. The extensive use of cellulase in many industries depends on the cost of the enzyme which in turn depends on the method of production. Hence, research all over the world focuses on isolating new, hyper producing microbial strains and also to develop new fermentation processes aimed at reducing the cost of the enzyme with a view to bring down the overall process cost (Tengerdy and Szakacs, 2003).

Physical and chemical methods have been widely used for the decolorization of dyes liberated by textile industries, but these methods are not feasible techniques since they are very expensive and forming hazardous by-products or intensive energy requirement (Patel et al., 2006). Microbial decolorization methods are commonly applied to treat textile industry effluents because various microorganisms, such as bacteria, yeasts, algae and fungi, are able to remove different classes of dyes (Tan et al.,
2013; Kelewou et al., 2014). Earlier researches confirmed that some ligninolytic fungi have the capacity to degrade synthetic dyes (Muthuchezhian et al., 2008) because of high laccase activity. Hence, the present study also aims to find out the reuse ability of fungal spent biomass after cellulase production for dye degradation.

\section{Materials and Methods}

\section{Biomass and culture organisms}

Fresh water hyacinth biomass (WHB) was collected from a local pond at Karaikudi, Tamilnadu, India $\left(10.07^{\circ} \mathrm{N}, 78.78^{\circ} \mathrm{E}\right)$. The collected samples were washed to remove adhering dirt, cut into small pieces ( 2 or 3 $\mathrm{mm})$ thickness and dried at sunlight. The fungal strains Trichoderma viride (NCIM 1195) and Aspergillus niger (NCIM 1255) were procured from the National Collection of Industrial Microorganism, Pune. Stock cultures of isolates were maintained on potato dextrose agar at $4^{\circ} \mathrm{C}$ and sub-cultured twice a month.

\section{FTIR characterization of cellulose of Water Hyacinth}

Fourier Transform Infrared spectra were studied on WHB using a Schimadzu spectrometer (Japan) in order to explore the characteristics of cellulose which was the sole carbon source for enzyme production. For this, $3.0 \mathrm{mg}$ of the sample was dispersed in $300 \mathrm{mg}$ of spectroscopic grade $\mathrm{KBr}$ and subsequently pressed into disks at $10 \mathrm{MPa}$ for $3 \mathrm{~min}$. The spectra were obtained with an average of 25 scans and a resolution of 4 $\mathrm{cm}^{-1}$ in the range of $4000-400 \mathrm{~cm}^{-1}$.

\section{Enzyme production}

The cellulase production was carried out by submerged fermentation process at optimized condition ( $\mathrm{pH} 6.0$; temp $32^{\circ} \mathrm{C}$ ) in 
$250 \mathrm{ml}$ conical flasks with $100 \mathrm{ml}$ of presterilized $\left(121^{\circ} \mathrm{C}\right.$ for $15 \mathrm{~min}$.) basal salt medium containing 5\% (w/v) powdered vegetative biomass of water hyacinth as a sole carbon source (Ariffin et al., 2006). The culture suspensions of $T$. viride and A. niger $(2 \% \mathrm{v} / \mathrm{v})$ were introduced separately in two sets of media and fermentation proceeded at $32{ }^{\circ} \mathrm{C}$ with agitation rate of $200 \mathrm{rpm}$ for 7 days. The supernatant obtained from the fermentation flask was treated with different saturation levels of ammonium sulphate (20, 40, 60 and 80\%), with continuous overnight stirring. The precipitated enzyme was collected by centrifugation and dissolved in $0.1 \mathrm{M}$ citrate buffer ( $\mathrm{pH}$ 5.0). The enzyme solution was dialyzed against the same buffer for $48 \mathrm{hrs}$ with several intermitted buffer changes. The partially purified enzyme obtained was lyophilized and used for further study (Arunachalam et al., 2010).

\section{Enzyme Assay}

Filter paper activity (FPase) (total cellulase activity) was determined according to the standard method (Ghose, 1987). $50 \mathrm{mg}$ of whatman No. 1 filter paper strip $[1 \times 6 \mathrm{~cm}]$ were immersed in $1 \mathrm{~mL}$ of $0.05 \mathrm{M}$ Sodium citrate buffer containing $0.1 \%$ of partially purified enzyme ( $\mathrm{pH}$ 5.0). After incubation at $50 \pm 2^{0} \mathrm{C}$ for $1 \mathrm{hr}$, the reducing sugar released was estimated by dinitrosalicylic acid [DNS] method (Miller, 1959). Endoglucanase activity (CMCase) was measured in the same method using a reaction mixture containing $1 \mathrm{~mL}$ of $1 \%$ carboxy methyl cellulose (CMC) in $0.5 \mathrm{M}$ citrate acetate buffer ( $\mathrm{pH}$ 5.0). The enzyme activities were expressed as IU ( $1 \mathrm{IU}=\mu \mathrm{mol}$ of reducing sugar released per minute per ml) (Tribak et al., 2002). $\beta$-glucosidase activity was assayed by the method of Ray et al., (1993) using a reaction mixture containing $0.2 \mathrm{~mL}$ of $5 \mathrm{mM} \rho$ - nitro phenyl $\beta$ - D - glucopyranoside (PNPG), $1.6 \mathrm{~mL}$ of $0.05 \mathrm{M}$ sodium citrate buffer $[\mathrm{pH} 4.8]$ and
$0.2 \mathrm{~mL}$ of enzyme solution. After incubation for 30 minutes at $50^{\circ} \mathrm{C}$ the reaction was stopped by the addition of $4 \mathrm{~mL}$ of $0.05 \mathrm{M}$ $\mathrm{NaOH}$ glycine buffer $(\mathrm{pH}$ 10.6) and the yellow colored $\rho$ - nitro phenyl was measured at $420 \mathrm{~nm}$. One unit of glucosidase activity is defined as that released mole of PNP from PNPG per minute per $\mathrm{ml}$ and the enzyme activity was expressed as micromole $(\mu \mathrm{mol})$ product (PNP) released per minute per $\mathrm{ml}$.

\section{Laccase Assay}

The laccase activity was determined using 2 , 2'-azino-bis (3-ethylbenzthiazoline-6sulphonic acid) (ABTS) as the substrate (Rasera et al. 2009). The laccase reaction mixture contained $0.5 \mathrm{ml}$ of $0.45 \mathrm{mM}$ ABTS, $1.2 \mathrm{ml}$ of $0.1 \mathrm{M}$ phosphate buffer ( $\mathrm{pH} 6.0$ ) and $0.5 \mathrm{ml}$ of fungal biomass to give a final reaction volume of $2.2 \mathrm{ml}$. The oxidation of the substrate (ABTS) was monitored by the increase in the absorbance at $420 \mathrm{~nm}$ using Shimadzu UV-1800 spectrophotometer (ELICO, India) over $90 \mathrm{~s}$ at $30^{\circ} \mathrm{C}$, using $\mathrm{e}=3.69104 \mathrm{~cm}^{-1} \mathrm{M}^{-1}$. Enzymatic activity was expressed as micromole $(\mu \mathrm{mol})$ product (ABTS) oxidized per min per $\mathrm{ml}$.

\section{Dye degradation}

Dye degradation was carried out in broth culture by the standard method (Talekar et al., 2011). The spent fungal biomass was recovered from the cellulase production media at the optimized period and inoculated into $250 \mathrm{ml}$ Erlenmeyer flask containing $100 \mathrm{ml}$ of sterilized basal medium containing azo dye. The above reaction mixture was incubated at $30^{\circ} \mathrm{C}$ with agitation speed of $200 \mathrm{rpm}$ for 6 days. The de-colorization of dye corresponds to the dye degradation potential of the fungal biomass. The dye degradation (\%) was measured using a spectrophotometer at a 
wavelength of $395 \mathrm{~nm}$ (Selvakumar et al., 2013).

\section{Results and Discussion}

\section{Characterization of cellulose of water hyacinth}

FTIR spectra of water hyacinth (Fig. 1) showed increased absorption bands at 1000 $1200 \mathrm{~cm}^{-1}$ that were related to structural features of cellulose and hemicelluloses. The peak at $1653 \mathrm{~cm}^{-1}$ was observed due to either the acetyl and uronic ester linkage of carboxylic group of the ferulic and pcoumeric acids of lignin and/or hemicelluloses (Hu et al., 2011). A sharp band at $896 \mathrm{~cm}^{-1}$, corresponding to the $\mathrm{C} 1$ group frequency or ring frequency, was attributed to the glycosidic linkages between xylose units in hemicelluloses (Marimuthu and Atmakuru, 2012). In the FTIR spectrum, the peaks observed at 1098 and $779 \mathrm{~cm}^{-1}$ were attributed to $\mathrm{C}-\mathrm{O}$ stretching and $\mathrm{C}-\mathrm{H}$ rocking vibration of cellulose structure.

\section{Enzyme Production}

Several industrial processes have been developed to utilize $\mathrm{WH}$ biomass as raw materials for the production of value added products such as single cell protein, extracellular enzymes and biologically active secondary metabolite etc (Fayyaz et al., 2009; Okunowo et al 2010). The present investigation was concerned to explore the possibility of using WH biomass as a substrate for the production of cellulases using $T$. viride and $A$. niger. The lignocellulosic biomass composition of $\mathrm{WH}$ includes cellulose $\left(20.2 \mathrm{~g} 100 \mathrm{~g}^{-1} \mathrm{DM}\right)$,

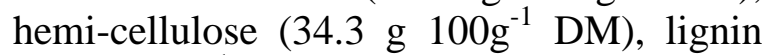

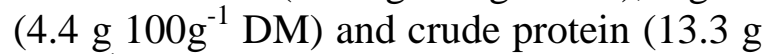
$\left.100 \mathrm{~g}^{-1} \mathrm{DM}\right)$ (Pothiraj et al., 2014).

The partial purification of crude enzyme by ammonium sulphate precipitation from the
72 hour culture (6d) gave total cellulase activity (FPase) of 68.3 (IU) for $T$. viride and 46.3 (IU) for A. niger which indicated significant increase in activity by $T$. viride over A. niger (Table 1). A similar result was reported by Milala et al., (2014) where ammonium sulphate precipitation of the 72 hour $R$. stolonifer culture gave cellulase activity of $33.00 \mathrm{U} \mathrm{ml}^{-1}$ at $80 \%$ saturation for millet stalk and $28.00 \mathrm{U} \mathrm{ml} \mathrm{m}^{-1}$ at $50 \%$ saturation in sawdust feed substrate.

Both the selected strains had produced maximum cellulase enzyme activity where the highest CMCase was exhibited by $T$. viride (98.4 (IU)) (Table 2).

A similar trend in enzyme production was also obtained by Usama et al. (2008) when the isolates were grown in submerged culture containing water hyacinth as the carbon source for A.niger and A.nidulans. Similarly, $T$. viride showed significantly increased $\beta$-glucosidase activity (71.9 IU) when compared with $A$. niger (58.9 IU) (Table 3).

Similar results were obtained with Trichoderma hamatum in rotten wood shavings after 144 hours cultivation (Chang et al., 2001) and the results were also basically consistent with previous findings of Fayyaz et al., (2009) in Tribolium castaneum. The results clearly showed that among the selected organisms $T$. viride was the efficient organism in concern with cellulase production in a shorter period.

\section{Compositional changes of WH biomass during fermentation}

\section{Cellulose Utilization}

Microorganisms which utilized cellulose as the preferred substrate for growth and enzyme activity could be more efficient in bioconversion process (Clavert, 2002). 
T.viride showed higher and faster utilization of cellulose than A.niger. More than $80 \%$ of cellulose $(80.15 \%)$ from water hyacinth biomass was utilized by T.viride while A.niger had utilized $70.7 \%$ of cellulose at the end of fermentation period (7d) (Table 4). Potential of these organisms can be well correlated with the activities of cellulose digesting enzymes such as CMCase, FPase and $\beta$-glucosidase activity. Similar results have been reported with earlier studies on cassava waste under solid state fermentation (Pothiraj et al., 2006).

\section{Reducing Sugar}

The maximum release of reducing sugar in WH during the fermentation process was expressed by T.viride (321.4 $\mathrm{mg} \mathrm{g}^{-1}$ ) followed by A.niger $\left(303.4 \mathrm{mg} \mathrm{g}^{-1}\right)$ on the $6^{\text {th }}$ day of fermentation (Table 5). T. viride giving a higher yield of reducing sugar may be due to its higher utilizing potential of $\mathrm{WH}$ biomass as carbon source. Baig et al., (2004) and Ojumu et al., (2003) had shown that the yield of reducing sugar was positively correlated with the production of cellulases in submerged fermentation of cellulosic substrates using fungi and actinomycetes.

\section{Reuse of spent fungal biomass for dye degradation}

The de-colorization of methylene blue in the reaction mixture confirmed the degradation potentials of spent fungal biomass. The maximum dye degradation (66\% and $61 \%$ ) was exhibited by the spent biomass of $T$. viride and A. niger, respectively (Fig. 2).

Table.1 Production of CMCase (IU) in submerged fermentation using Water hyacinth

\begin{tabular}{|l|c|c|c|c|c|c|c|}
\hline \multirow{2}{*}{ Organisms } & \multicolumn{7}{|c|}{ Period of fermentation (Days) } \\
\cline { 2 - 8 } & $\mathbf{1}$ & $\mathbf{2}$ & $\mathbf{3}$ & $\mathbf{4}$ & $\mathbf{5}$ & $\mathbf{6}$ & $\mathbf{7}$ \\
\hline T. viride & $10.3 \pm 0.5$ & $28.3 \pm 1.9$ & $33.9 \pm 3.1$ & $55.8 \pm 3.3$ & $79.3 \pm 6.5$ & $98.4 \pm 6.1$ & $78.3 \pm 5.1$ \\
\hline A. niger & $7.3 \pm 0.3$ & $21.8 \pm 1.3$ & $28.1 \pm 1.3$ & $48.3 \pm 3.9$ & $63.3 \pm 5.5$ & $72.3 \pm 6.5$ & $61.7 \pm 4.1$ \\
\hline
\end{tabular}

Table.2 Production of total cellulase (FPase) (IU) in submerged fermentation using Water hyacinth

\begin{tabular}{|l|c|c|c|c|c|c|c|}
\hline \multirow{2}{*}{ Organisms } & \multicolumn{7}{|c|}{ Period of fermentation (Days) } \\
\cline { 2 - 8 } & $\mathbf{1}$ & $\mathbf{2}$ & $\mathbf{3}$ & $\mathbf{4}$ & $\mathbf{5}$ & $\mathbf{6}$ & $\mathbf{7}$ \\
\hline T. viride & $6.7 \pm 0.4$ & $13.5 \pm 0.9$ & $22.3 \pm 1.7$ & $31.4 \pm 2.8$ & $43.9 \pm 3.2$ & $68.3 \pm 4.3$ & $57.5 \pm 3.8$ \\
\hline A. niger & $4.1 \pm 0.1$ & $9.8 \pm 0.3$ & $18.3 \pm 1.1$ & $21.8 \pm 1.1$ & $31.8 \pm 2.9$ & $46.3 \pm 2.7$ & $35.3 \pm 2.1$ \\
\hline
\end{tabular}

Results are mean $\pm \mathrm{SE}$ of three replicates

Table.3 Production of $\beta$-glucosidase (IU) in submerged fermentation using Water hyacinth

\begin{tabular}{|l|c|c|c|c|c|c|c|}
\hline \multirow{2}{*}{ Organisms } & \multicolumn{7}{|c|}{ Period of fermentation (Days) } \\
\cline { 2 - 8 } & $\mathbf{1}$ & $\mathbf{2}$ & $\mathbf{3}$ & $\mathbf{4}$ & $\mathbf{5}$ & $\mathbf{6}$ & $\mathbf{7}$ \\
\hline T. viride & $8.3 \pm 0.3$ & $17.5 \pm 0.9$ & $28.7 \pm 1.9$ & $39.3 \pm 1.9$ & $58.7 \pm 3.5$ & $71.9 \pm 5.4$ & $63.4 \pm 2.9$ \\
\hline A. niger & $5.3 \pm 0.3$ & $13.5 \pm 1.1$ & $21.3 \pm 1.8$ & $33.4 \pm 1.9$ & $44.8 \pm 2.8$ & $58.9 \pm 4.1$ & $48.7 \pm 2.8$ \\
\hline
\end{tabular}


Table.4 Cellulose utilization (\%) during the submerged fermentation of WHB

\begin{tabular}{|l|c|c|c|c|c|c|c|}
\hline \multirow{2}{*}{ Organisms } & \multicolumn{7}{|c|}{ Period of fermentation (Days) } \\
\cline { 2 - 8 } & $\mathbf{1}$ & $\mathbf{2}$ & $\mathbf{3}$ & $\mathbf{4}$ & $\mathbf{5}$ & $\mathbf{6}$ & $\mathbf{7}$ \\
\hline T. viride & $6.73 \pm 0.62$ & $25.15 \pm 1.9$ & $31.93 \pm 2.2$ & $48.81 \pm 3.7$ & $61.73 \pm 4.7$ & $80.05 \pm 4.2$ & $80.15 \pm 5.3$ \\
\hline A. niger & $5.15 \pm 0.41$ & $17.48 \pm 1.3$ & $21.98 \pm 1.7$ & $35.25 \pm 2.4$ & $51.39 \pm 3.9$ & $70.40 \pm 4.7$ & $70.69 \pm 4.1$ \\
\hline
\end{tabular}

Results are mean \pm SE of three replicates.

Table.5 Reducing sugar release (mg g-1) during the submerged fermentation by fungal isolates

\begin{tabular}{|l|c|c|c|c|c|c|c|}
\hline \multirow{2}{*}{ Organisms } & \multicolumn{7}{|c|}{ Period of fermentation (Days) } \\
\cline { 2 - 8 } & $\mathbf{1}$ & $\mathbf{2}$ & $\mathbf{3}$ & $\mathbf{4}$ & $\mathbf{5}$ & $\mathbf{6}$ & $\mathbf{7}$ \\
\hline T. viride & $63.1 \pm 3.8$ & $121.3 \pm 9.4$ & $198.8 \pm 9.3$ & $227.6 \pm 18.3$ & $287.5 \pm 16.5$ & $321.4 \pm 9.6$ & $313.5 \pm 18.3$ \\
\hline A. niger & $54.5 \pm 3.3$ & $114.8 \pm 9.8$ & $168.7 \pm 8.4$ & $208.3 \pm 16.3$ & $273.5 \pm 14.1$ & $303.4 \pm 8.5$ & $290.5 \pm 13.4$ \\
\hline
\end{tabular}

Results are mean \pm SE of three replicates.

Fig.2 Dye decolourization potential (\%) and laccase activity (IU) of the spent fungal biomass

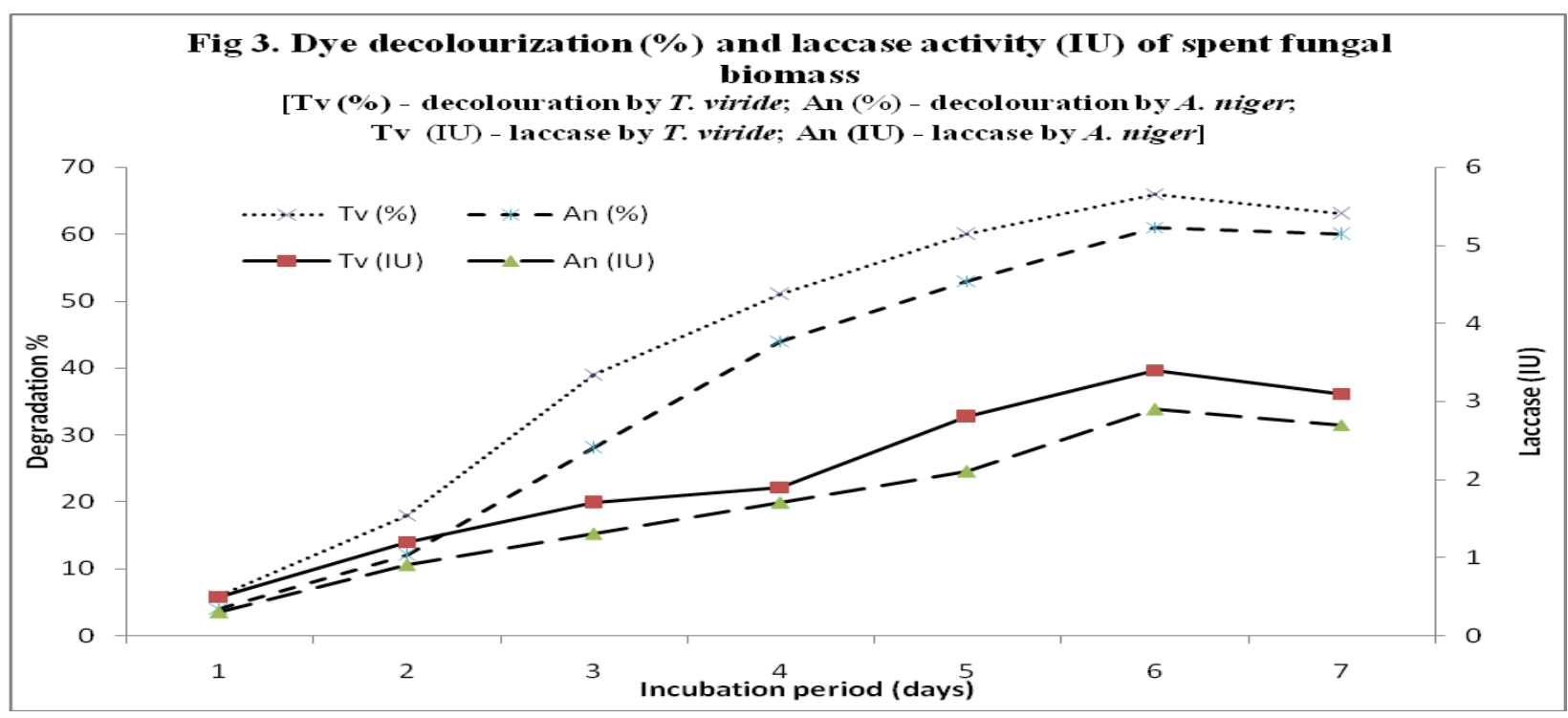


Int.J.Curr.Microbiol.App.Sci (2016) 5(10): 99-108

Fig.1 FTIR spectra of Water Hyacinth Biomass

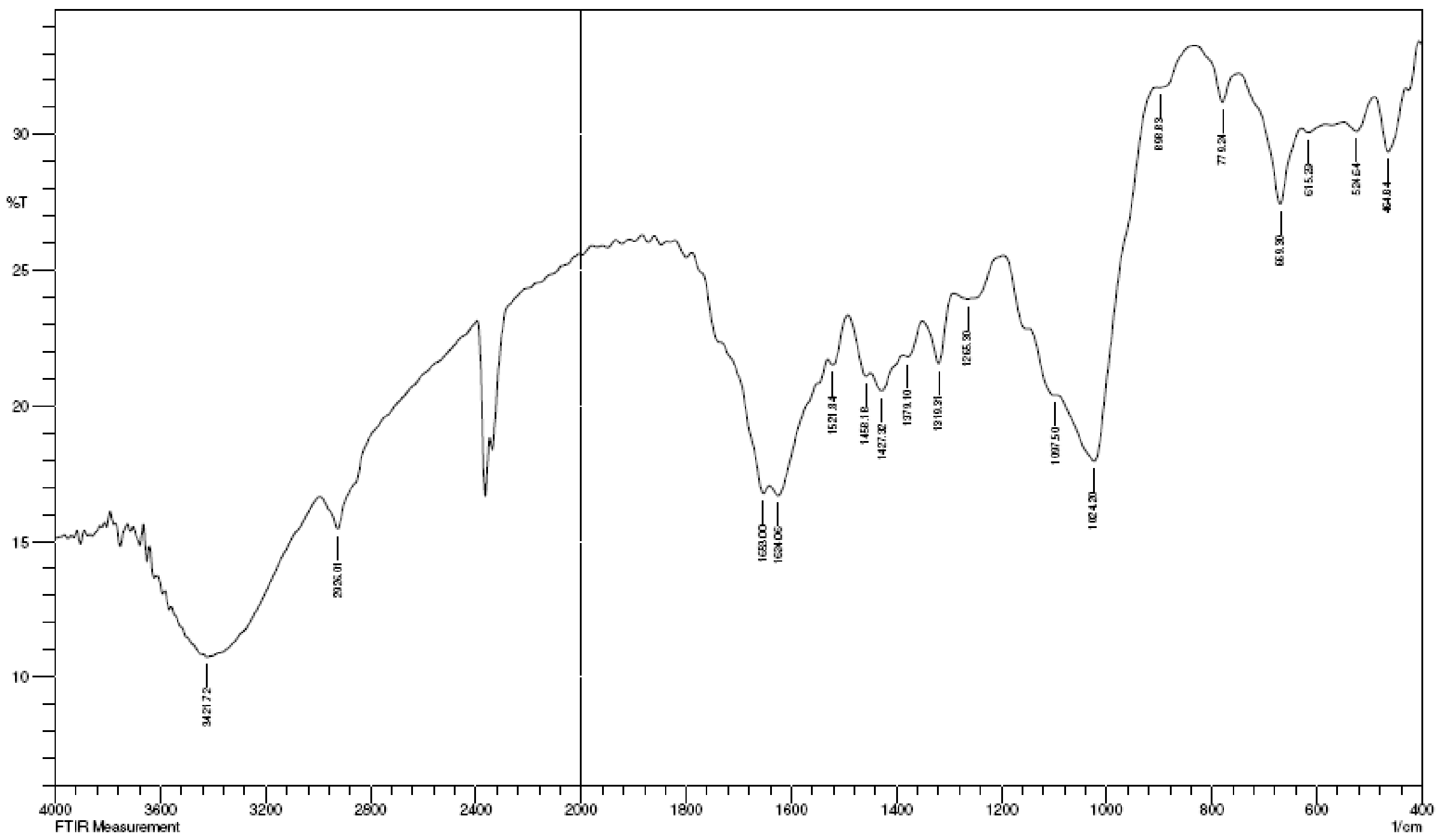


Similar dye de-colorization was observed by fungal isolates from dye industry waste (Selvakumar et al., 2013). The present results clearly demonstrated the dye degradation potential of isolated fungus and confirmed the ability of spent fungal biomass for dye de-colourization after cellulase enzyme production. The laccase activity was measured and the results were showed in Fig. 2. It was inferred from the results that the laccase activity increased up to 6th day with a maximum activity of 3.4 (IU) for T. viride and 2.9 (IU) for A. niger. The de-colourization process depends on the increased or decreased enzyme production by the spent fungal biomass (Vinothkumar et al., 2011).

In conclusion, using water hyacinth as carbon sources, cellulase was produced in submerged fermentation by T.viride and $A$. niger and the production parameters were optimized. The partially purified crude enzyme of $T$. viride exhibited significantly higher total cellulase activity (FPase) of 68.3 (IU), CMCase (98.4 IU) and glucosidase (71.9 IU) compared to A. niger. The dye degradation potential of both fungal strains $(66 \% \& 61 \%)$ confirmed the ability of spent fungal biomass for dye de-colourization after cellulase enzyme production. Hence, it can be used for dye degradation in water bodies polluted with textile effluents. The present study reveals that the WHB associated fungi can be used to produce industrially valuable enzymes by submerged fermentation.

\section{Acknowledgement}

The authors thank the Tamilnadu state council for higher education (TANSCHE) for their financial support to successfully execute this research work.

\section{References}

Ariffin, H., Abdullah, N., Umi Kalsom, M.S., Shirai, Y. and Hassan, M.A. 2006. Production and characterisation of cellulase by bacillus pumilus eb3. Int. J. Eng. Technol., 3(1): 47-53.

Arunachalam, R., Wesely, EG., George, J. and Annadurai, G. 2010. Novel Approaches for identification of Streptomyces noboritoensis TBG-V20 with cellulase production. Curr. Res. Bacteriol., 3(1): 15-26.

Baig, M.M.V., M.L.B. Baig, M.L.B., Baig, M.I.A. and Majeda, Y. 2004. Saccharification of banana agro waste. J. Biotechnol., 3(9): 447-450.

Camassola, M. and Dillon, A.J.P. 2009. Biological pretreatment of sugar cane bagasse for the production of cellulases and xylanases by Penicillium echinulatum. Ind. Crop. Prod., 29: 642647.

Clavert, P. 2002. Water hyacinth: control and possible uses. Technical brief. International Technology Development centre. UK

Esteghlalian, A., Hashimoto, A.G., Fenske, J.J. and Penner, M.H. 1997. Modeling and optimization of the dilute-sulfuricacid pre-treatment of corn stover, poplar and switch grass. Bioresour. Technol., 59:129-36.

Fayyaz, U.R., Mehwish, A., Ilyas Tariq, M., Ashraf, S., Sami, A.J., Naima, H.N. and Batool, A.I. 2009. Isolation of cellulolytic activities from Tribolium castaneum (red flour beetle). Afri. J. Biotechnol, 8(23): 6710-6715.

Ghose, T.K. 1987. Measurement of cellulose activities. Pure Applied Chem., 59: 257 268.

Hahn-Hägerdal, B., Galbe, M., GorwaGrauslund, M.F., Liden, G. and Zacchi, G. 2006. Bioethanol the fuel of 
tomorrow from the residues of today. Trends Biotechnol., 24: 549- 56.

$\mathrm{Hu}$, J., Arantes, J. and Saddler, J.N. 2011. The enhancement of enzymatic hydrolysis of lignocellulosic substrates by the addition of accessory enzymes such as xylanase: is it an additive or synergistic effect, Biotechnol. Biofuel., 4: 36.

Kelewou, H., Merzouki, M. and Lhassani, A. 2014. Biosorption of textile dyes Basic Yellow 2 (BY2) and Basic Green 4 (BG4) by the live yeast $\mathrm{S}$. cerevisiae, J. Mater. Environ. Sci., 5(2): 633-640.

Kim, S. and Holtzapple, M.T. 2006. Effect of structural features on enzyme digestibility of corn stover. Bioresour. Technol., 97(4): 583-591.

Lu, W.P., Wang, C. and Yang, Z.Y. 2009. The preparation of high caloric fuel (HCF) from water hyacinth by deoxyliquefaction. Bioresour. Technol., 100: 6451-6456.

Lynd, L.R., Elander, R.T. and Wyman, C.E. 1996. Likely features and costs of mature biomass ethanol technology. Appl. Biochem. Biotechnol., 57/58:741761.

Marimuthu, T.S. and Atmakuru, R. 2012. Isolation and characterization of cellulose nanofibers from the aquatic weed water hyacinth-Eichhornia crassipes. Carbohydrate Polymers, 87: 1701.

Mathew, G.M., Sukumaran, R.K., Singhania, R.R. and Pandey, A. 2008. Progress in research on fungal cellulases for lignocellulose degradation. J Sci. Indust. Res., 67: 898 $-907$.

Milala, M.A., Shugaba, A., Zauna, H. And Appollos, B. 2014. Isolation and Partial Purification of Cellulase from Rhizopus Stolonifer. J Sci. Tech., 4(8): 433 - 437.

Miller, L. 1959. Use of dinitro salicylicacid reagent for determination of reducing sugars. Anal. Chem., 31: 426-428.

Mishima, D., Kuniki, M., Sei, K., Soda, S., Ike, M. and Fujiata, M. 2008. Ethanol production from candidate energy crops: Water hyacinth (Eichhornia crassipes) and water lettuce (Pistia stratiotes L.). Bioresour. Technol., 99: 2495-2500.

Mishima, D., Tateda, M., Ike, M. and Fujita, M. 2006. Comparative study on chemical pretreatments to accelerate enzymatic hydrolysis of aquatic macrophyte biomass used in water purification processes. Bioresour. Technol., 97: 2166-2172.

Mukhopadhyay, S., Mukherjee, P.S. and Chatterjee, N.C. 2008. Optimization of enzymatic hydrolysis of water hyacinth by Trichoderma reesi vis production of fermentable sugars. Acta Aliment, 37: 367-377.

Muthuchezhian, R., Yoganath, N., Vidya, S. and Jayalakshmi, S. 2008. Dye degrading mycofloflora from industrial effluents. Res. J. Microbiol., 3: 204208.

Ojumu, T.V., Solomon, B.O., Betiku, E., Layokun, S.K. and Amigun, B. 2003. Cellulase production by Aspergillusflavus Linn isolate NSPR 101 fermented in saw dust, bagasse and corn cob. Afri. J. Biotechnol., 2: 150152.

Okunowo, W.O., Gbenle Go., Osuntoki, A.A., Adekunle, A.A. and Ojokuku, S.A. 2010. Production of cellulolytic and xylanolytic enzymes by a phytopathogenic Myrothecium roridum and some avirulent fungal isolates from water hyacinth. Afri. J. Biotechnol., 9: 1074-1078.

Patel, R. and Suresh, S. 2006. Decolourization of azo dyes using magnesium- palladium system. $J$. Hazard. Mater. 137: 1729-1741.

Pothiraj, C., Arumugam, R. and Eyini, M. 
2014. Sustaining ethanol production from lime pretreated water hyacinth biomass using mono and co-cultures of isolated fungal strains with Pichia stipitis. Bioresour. Bioprocess, 27: 1 27.

Pothiraj, C., Balaji, P. and Eyini, M. 2006. Enhanced production of cellulases by various fungal cultures in solid state fermentation of cassava waste. Afri. $J$. Biotechnol., 5: 1882 - 1885.

Rasera, K., Ferla, J., Dillon, A.J.P., Riveiros, R. and Zeni, M. 2009. Immobilization of laccase from Pleurotus sajor-caju in polyamide membranes. Desalin, 245: 657-661.

Ray, L., Pal, A., Ghose, A. K. and Chattodhyay, P. 1993. Cellulases and $\beta$ glucosidase from A. niger and saccharification of some cellulosic wastes, J. Microbio. Biotechnol., 8: 8594.

Selvakumar, S.R., Manivasagam, R. and Chinnapan, K. 2013. Biodegradation and decolourization of textile dye waste water using Ganoderma lucidum. Biotech., 3: 71-79.

Singhal, V. and Rai, J.P.N. 2003. Biogas production from water hyacinth and channel grass used for phytoremediation of industrial effluents. Bioresour. Technol., 86: 221225.

Talekar, S., Ghodake, V., Chavare, S., Ingrole, R.. Kate Magdum, S. and Pillai, M. 2011. Production and characterization of cellulose by local fungal isolate of india using water hyacinth as carbon source and reuse of fungal biomass for dye degradation. Int. J. Engi. Sci. Technol., 3(4): 3236-3241.

Tan, L., Ning, S., Zhang, X. and Shi, S. 2013. Aerobic decolorization and degradation of azo dyes by growing cells of a newly isolated yeast Candida tropicalis TL-F1, Bioresour. Technol., 138: 307-313.

Tengerdy, R.P. and Szakacs, G. 2003. Bioconversion of lignocellulose in solid substrate fermentation. Biochem. Engi. J., 13: 169-179.

Usama, F., Ali, and Saad El-Dein, H.S. 2008. Production and partial purification of cellulase complex by Aspergillus niger and A.nidulans grown on water hyacinth blend. J. Appl. Sci. Res., 4(7): 875-891.

Vinothkumar, V., Kirupha, S.D., Periyaraman, P. and Sivanesan, S. 2011. Screening and induction of laccase activity in fungal species and its application in dye decolorization. Afri. J. Microbiol. Res., 5: 1261-1267.

Wang, L.S., Zhang, Y.Z., Gao, P.J., Shi, D.X., Liu, H.W., Gao, H.J. 2006. Changes in the structural properties and rate of hydrolysis of cotton fibers during extended enzymatic hydrolysis. Biotechnol. Bioeng., 93(3): 443-456.

Zhao, S., Liang, X., Hua, D., Ma, T. and Zhang, H. 2011. High-yield cellulase production in solid-state fermentation by Trichoderma reesei SEMCC-3.217 using water hyacinth (Eichhornia crassipes). Afri. J. Biotech., 10(50): 10178-10187.

\section{How to cite this article:}

Pothiraj, C., R. Arumugam and Gobinath, R.M. 2016. Production of Cellulase in Submerged Fermentation using Water Hyacinth as Carbon Source and Reutilization of Spent Fungal Biomass for Dye Degradation. Int.J.Curr.Microbiol.App.Sci. 5(10): 99-108. doi: http://dx.doi.org/10.20546/ijcmas.2016.510.012 